\title{
Primary tumours of the optic nerve and the optic nerve sheath
}

\section{Pierwotne guzy nerwu wzrokowego i jego ostonek}

\author{
Kamila Krasodomska¹, Wojciech Lubiński1 ${ }^{\boxplus}$, Marta Masztalewicz², Lech Cyryłowski³ \\ 1 Pomorski Uniwersytet Medyczny w Szczecinie, II Klinika Okulistyki, al. Powstańców Wlkp. 72, 70-111 Szczecin \\ Pomeranian Medical University in Szczecin, II Chair and Department of Ophthalmology \\ ${ }^{2}$ Pomorski Uniwersytet Medyczny w Szczecinie, Katedra i Klinika Neurologii, ul. Unii Lubelskiej 1, 71-252 Szczecin \\ Pomeranian Medical University in Szczecin, Chair and Department of Neurology \\ ${ }^{3}$ Pomorski Uniwersytet Medyczny w Szczecinie, Zakład Radiologii Zabiegowej, al. Powstańców Wlkp. 72, 70-111 Szczecin \\ Pomeranian Medical University in Szczecin, Department of Interventional Radiology \\ $\triangle$ lubinski@pro.onet.pl
}

\begin{abstract}
Introduction: Glioma and meningioma, the 2 most common primary tumours of the optic nerve and optic nerve sheath are usually benign, slow-growing tumours.

The aim of the paper is to provide an overview of clinical, histological and radiological features of the most common primary tumours of the optic nerve and optic nerve sheath, as well as to discuss available treatment options.

Materials and methods: A literature review was performed based on articles discussing optic nerve glioma and meningioma of the optic nerve sheath.

Results: Glioma is the most common primary tumour of the optic nerve. In $90 \%$ of the patients, the onset is within the first 2 decades of life. Meningioma is the most common primary tumour of the optic nerve sheath. In $95 \%$ of the sufferers, the onset is in adulthood. Although rare in the general population, primary tumours of the optic nerve and its sheath are seen more often in patients with neurofibromatosis (NF). Glioma more
\end{abstract}

often affect patients with $\mathrm{NF} 1$, whereas meningiomas more often affect those with NF2. Unlike in children, optic nerve glioma in adults can be malignant. On the other hand, optic nerve sheath meningioma tends to be more malignant in children rather than in adults. The symptoms of optic nerve glioma and optic nerve sheath meningioma can be similar, including vision impairment and proptosis. The diagnosis is based on orbital imaging with magnetic resonance image (MRI) or computed tomography (CT). The management most often involves clinical observation. Surgery, radiation therapy or chemotherapy are only used in selected cases with the risk of optic chiasm or fellow optic nerve involvement.

Conclusions: Primary tumours of the optic nerve and optic nerve sheath are rare. Consolidated knowledge and improved understanding can aide early diagnosis and proper management of such cases.

Keywords: optic nerve glioma; optic nerve sheath meningioma.

\begin{abstract}
ABSTRAKT
Wstęp: Najczęstsze pierwotne guzy nerwu wzrokowego i jego osłonek, tj. odpowiednio glejaki i oponiaki, są przeważnie łagodnymi nowotworami o powolnym przebiegu.

Celem niniejszej pracy było przedstawienie cech klinicznych, histopatologicznych, radiologicznych oraz postępowania w najczęstszych pierwotnych guzach nerwu wzrokowego i jego osłonek.

Materiały i metody: Na podstawie wyników dostępnych w piśmiennictwie dokonano analizy glejaków nerwu wzrokowego i oponiaków osłonek nerwu wzrokowego.

Wyniki: Najczęstszym pierwotnym guzem nerwu wzrokowego jest glejak, którego objawy u 90\% pacjentów pojawiają się w ciągu pierwszych 2 dekad życia. Natomiast najczęstszy pierwotny guz osłonek nerwu wzrokowego to oponiak, w 95\% ujawniający się $\mathrm{w}$ wieku dorosłym. Pierwotne guzy nerwu wzrokowego i jego osłonek zwykle występują sporadycznie, ale częściej obserwuje się je u pacjentów z neurowłókniakowatością (neurofibromatosis - NF) - w NF typu 1 - glejaki, a w NF typu 2 - oponiaki. W przeciwieństwie do glejaków nerwu wzrokowego u dzieci
\end{abstract}

te występujące u osób dorosłych mogą mieć złośliwy przebieg. Oponiaki osłonek nerwu wzrokowego natomiast bardziej złośliwy przebieg wykazują w wieku dziecięcym. Objawy glejaków nerwu wzrokowego oraz jego osłonek mogą być podobne - pogorszenie widzenia, wytrzeszcz. Głównym narzędziem diagnostycznym ułatwiającym postawienie rozpoznania są badania obrazowe oczodołów, tj. rezonans magnetyczny (magnetic resonance image - MRI) lub tomografia komputerowa (computed tomography - CT). W postępowaniu najczęściej stosuje się obserwację kliniczną, a tylko w wybranych przypadkach - zagrażających zajęciem skrzyżowania nerwów wzrokowych lub towarzyszącego nerwu wzrokowego - leczenie obejmujące neurochirurgiczne wycięcie, radioterapię lub chemioterapię.

Wnioski: Pierwotne guzy nerwu wzrokowego i jego osłonek należą do rzadko występujących. Usystematyzowanie wiedzy na ich temat umożliwi wczesną diagnostykę tych schorzeń oraz prawidłowe postępowanie.

Słowa kluczowe: glejak nerwu wzrokowego; oponiak osłonek nerwu wzrokowego. 


\section{INTRODUCTION}

Primary optic nerve tumours can be divided into those affecting the optic nerve only and those affecting the optic nerve sheath. These are quite rare. Optic nerve glioma (ONG), which constitute $1 \%$ of all intracranial tumours is the most common primary optic nerve tumour. On the other hand, optic nerve sheath meningioma (ONSM) which constitutes about $1-2 \%$ of all intracranial meningiomas is the most common primary optic nerve sheath tumour $[1,2,3,4]$. The ONG is a slow-growing tumour, with typical transient stages of accelerated or inhibited growth. Spontaneous regression is not uncommon [5]. It is considered a locally malignant tumour originating from the glial cells of the optic nerve. It normally spreads within the optic nerve without distant metastases and may only spread to the optic chiasm or other parts of the brain (e.g. hypothalamus) in exceptional cases. Similarly, the primary ONSM which originates from the arachnoid and may spread both within the orbit and into the cranial cavity, is a locally malignant tumour. The classification system proposed by Schick et al. [3] differentiates between 3 types of ONSM: type 1 - purely intraorbital lesion, type 2 - intraorbital ONSMs with extension through the optic canal or superior orbital fissure, and type 3 - intraorbital lesion with widespread intracranial tumour extension. Apart from primary ONG and ONSM, other optic nerve tumours may also develop, such as ganglioglioma, medulloepithelioma, haemangioblastoma and schwannoma [4].

The aim of this paper is to present current knowledge, clinical, radiological and histological features of primary ONG and ONSM, which slowly cause vision impairment leading to blindness, as well as presenting current treatment options.

\section{EPIDEMIOLOGY AND HISTOLOGICAL FEATURES}

\section{Primary optic nerve glioma}

Primary ONG is the most common optic nerve tumour more frequently seen in women. It is usually unilateral. The onset is possible at any age, although primary ONG are most commonly seen in children. According to Chutorian et al. [6], primary ONG

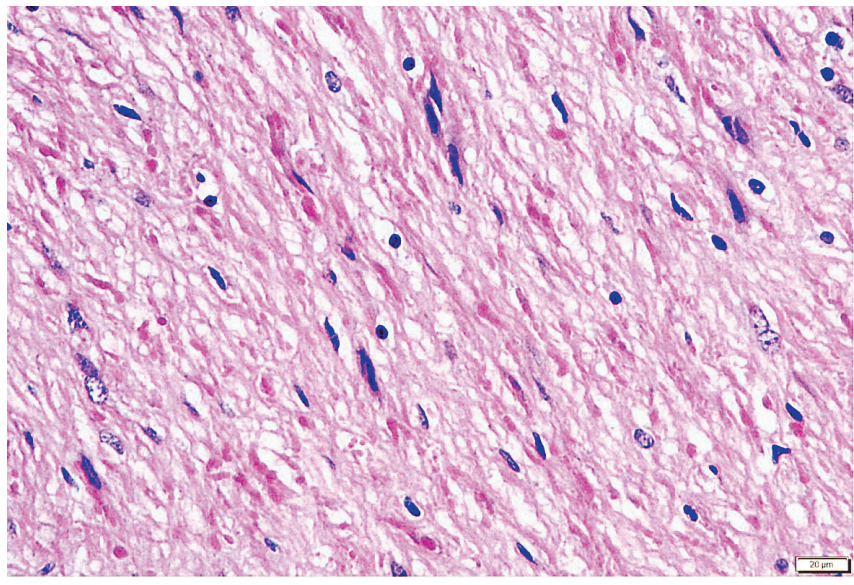

FIGURE 1. Histological image of pilocytic astrocytoma (magnification: 200x) develops within the $1^{\text {st }}$ decade of life in $75 \%$ of patients and within the first 2 decades of life in $90 \%$ of patients. Although most ONGs are sporadic, the tumour seems to occur more often in patients with neurofibromatosis type $1(\mathrm{NF} 1)$. Concomitant ONG is seen in $15-20 \%$ of patients with NF1 and, just as in children, it is a low grade tumour [4, 7]. Primary ONG develops infrequently in adults. Onset between the $2^{\text {nd }}$ and the $8^{\text {th }}$ decade of life is usually associated with a higher grade (grade III-IV) and the tumour quickly spreads to the optic chiasm, leading to blindness and death within a few months $[4,8]$.

Pilocytic astrocytoma, composed of thin hair-like, spindle cells (Fig. 1), is the most common primary ONG. It is classified as Grade I according to the World Health Organization (WHO), that is, a well differentiated tumour of low malignant potential.

\section{Primary optic nerve sheath meningioma}

Primary ONSM constitutes $2 \%$ of all orbital tumours being the $2^{\text {nd }}$ most common optic nerve tumour (with ONG as the most common one) $[2,3,9]$. Primary ONSM may occur at any age in both sexes, being more common in women at around the $5^{\text {th }}$ decade of life. It hardly affects children and individuals below 20 years of age (only $5 \%$ of cases) [10]. Primary ONSMs are usually unilateral and, in most cases, benign (except for those seen in children which tend to be malignant). Primary ONSMs more often affect patients with neurofibromatosis type $2(\mathrm{NF} 2)$ and are found in $9 \%$ and $35 \%$ of adults and children, respectively [11].

Histologically, cells forming a convolutional pattern (Fig. 2) or a typical cobblestone morphology, containing small globular calcific collections (psammoma bodies) are seen.

\section{CLINICAL MANIFESTATION}

\section{Primary optic nerve glioma}

Optic nerve gliomas are painless and cause vision impairment accompanied by proptosis as the tumour progresses, often with strabismus. The optic nerve of a patient with primary ONG may be normal, oedematous or pale. Some patients may develop central retinal vein occlusion, venous stasis

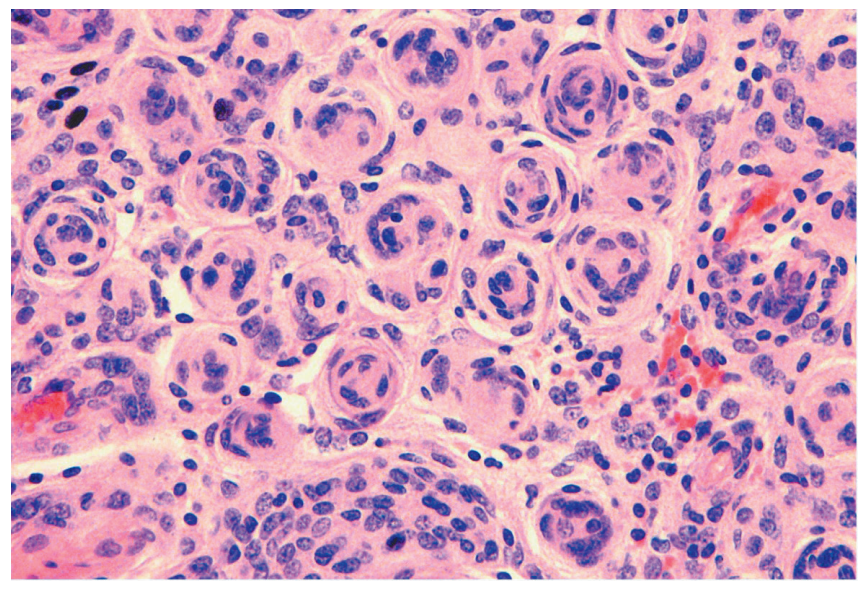

FIGURE 2. Histological image of optic nerve meningioma (magnification: 100×) 
retinopathy, and sometimes neovascularisation of the iris with neovascular glaucoma due to long-term compression of the central retinal vein. Some ONGs, especially concomitant with NF1, remain asymptomatic and may be found accidentally at screening [12].

On the other hand, the adult-onset gliomas, unrelated to NF1, cause sudden vision impairment soon followed by neurological symptoms. If a tumour is located within the distal part of the optic nerve, the fundus may appear normal, whereas tumours located more proximally within the optic nerve, cause numerous retinal haemorrhages resembling central retinal vein occlusion. Proptosis is not typical of adult-onset ONG $[4,13]$.

\section{Primary optic nerve sheath meningioma}

Patients with primary ONSM usually present worsening or blurred vision in the affected eye. They may also report colour vision abnormalities, especially monocular red desaturation compared to the other eye. Some complain about pain upon eye movement or report transient vision loss lasting for a few seconds. Proptosis or strabismus usually occur at later stages, with permanent vision impairment or blindness [4, 10]. Just as in primary $\mathrm{ONG}$, the optic nerve of a patient with primary ONSM may be normal, oedematous or pale. A typical triad of symptoms including vision loss, optic nerve atrophy and optic disc neovascularisation, are often pathognomonic for ONSM. However, optic disc neovascularisation is only seen in $1 / 3$ of cases, as it is hardly detectable with a routine ocular examination and can resolve with optic nerve atrophy [14].

\section{RADIOLOGICAL FEATURES}

\section{Primary optic nerve glioma/optic nerve sheath meningioma}

Both ONG and ONSM are diagnosed based on computed tomography (CT) or magnetic resonance image (MRI). Patients with ONG present spindle-shaped, well demarcated optic nerve thickening without dural involvement (Fig. 3). More sensitive MRI may detect tumour expansion beyond the optic nerve

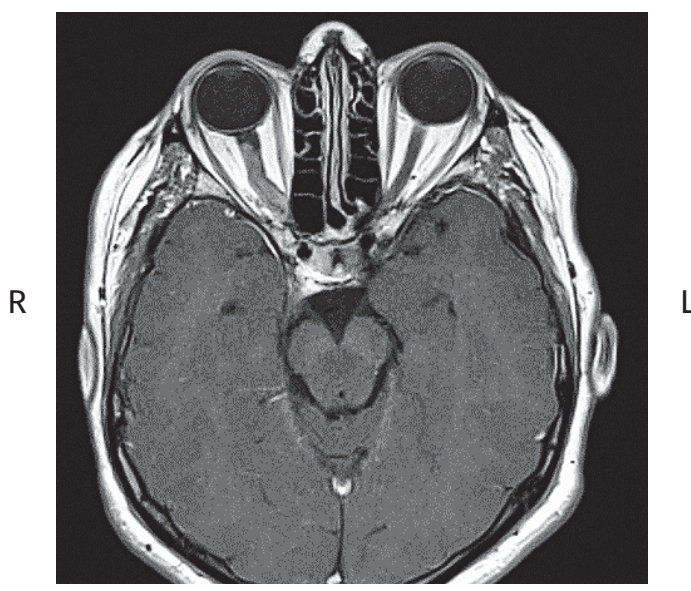

FIGURE 3. Magnetic resonance image of the primary right optic nerve glioma to the optic chiasm, which cannot be seen in the CT. Following administration of gadolinium-based contrast medium, some ONGs show partial or total enhancement, which is considered evidence of their high metabolic activity [4, 15]. With ONSM, calcific collections surrounding the optic nerve are common, seen in $20-50 \%$ of cases, which form a characteristic "tram track" pattern (Fig. 4). Furthermore, tubularoptic nerve enlargement was described with homogeneous tumour enhancement following gadolinium administration $[4,14]$.

\section{TREATMENT}

Long-term observation indicates that patients with ONG usually have very good or at least stable visual acuity if left untreated. Thus, preventive tumour resection for the fear of its spreading to the fellow eye, which is extremely rare, is not justified. Miller [4] and Lee [16] state that surgical resection of ONGs causing irreversible vision loss in the affected eye should only be performed in patients with 1) aesthetically unacceptable proptosis, causing severe pain and exposure keratopathy, or 2) radiologically confirmed tumour expansion. Treatment of primary ONGs with vincristin- or carboplatin-based chemotherapy regimens is controversial. The outcomes after chemotherapy are no better than after clinical observation [17]. Bilgin et al. [8] retrospectively studied 11-year follow-ups of patients with histologically confirmed adult-onset grade I-II ONG. They reported a series of 3 cases of ONG in patients aged 31-45 years, with symptoms lasting for 1-3 months prior to diagnosis. Each of them presented no light sensation within the year following the onset. They were treated with radiotherapy, combined chemoradiotherapy or systemic steroids. One patient had died within a year following the diagnosis (malignant transformation was suspected), but there was no progression with the remaining two. The authors emphasized that whereas malignant (grades III-IV) ONG in adults have been well described in literature, benign ones (grades I-II) had been reported significantly less often and were often misdiagnosed as optic neuritis or non-arteritic anterior ischemic optic neuropathy.

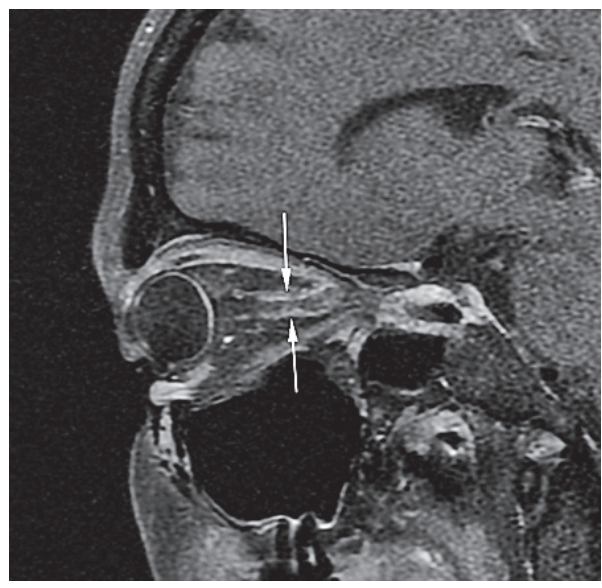

FIGURE 4. Magnetic resonance image of primary optic nerve meningioma (the arrow points to the 'tram track sign') 
Wulc et al. [18] reported only 7 cases of ONG (pilocytic astrocytoma) in patients aged 18-61 years over 38-year follow-ups. Similarly, other authors $[19,20]$ also reported single cases of benign $0 N G$ in adult patients. Biopsy enables tumour grading according to the WHO classification, especially in fast-growing tumours. However, even grade I tumours in this age group may need treatment to protect the fellow eye [8].

Primary ONSMs in adults are usually associated with good visual acuity maintained many years, unchanged life expectancy and do not usually cause neurological impairment or spread to the fellow eye $[4,11,21]$. Vision loss in an eye with ONSM may occur even after several decades following the diagnosis [4]. Surgical resection of ONSM is always associated with irreversible blindness in the affected eye as damage-free separation of the optic nerve from the surrounding tumour tissue is impossible. In the past, 2 alternatives were possible: tumour (and optic nerve) resection or clinical observation whilst vision in the affected eye deteriorated gradually. Most patients and doctors chose the latter [4]. Currently, intensity modulated radiotherapy (IMRT) appears a promising treatment option. The outcomes of radiotherapy in primary ONSMs included stable visual acuity and inhibited tumour progression [22]. Miller [4] postulates clinical observation in patients with ONSM and good visual acuity until subjective and objective impairment is confirmed, upon which radiotherapy can be considered, while patients with severe vision impairment should be referred immediately for radiotherapy. The followup assessments should be scheduled every 3-6 months, with neuroimaging performed every 6-12 months. Upon confirming intracranial tumour expansion in patients with functional visual acuity, surgical intervention should be considered in order to protect the fellow eye.

\section{CONCLUSIONS}

The management of patients with primary ONG and primary ONSM should always be discussed. Due to the slow-growing and benign nature of these tumours, clinical observation with regular ophthalmic follow up and neuroimaging may often be sufficient. Surgery, radiation therapy or chemotherapy are only used in selected cases.

\section{REFERENCES}

1. Dutton JJ. Gliomas of the anterior visual pathway. Surv Ophthalmol 1994;38(5):427-52.

2. Shapey J, Sabin HI, Danesh-Meyer HV, Kaye AH. Diagnosis and management of optic nerve sheath meningiomas. J Clin Neurosci 2013;20(8):1045-56.

3. Schick U, Jung C, Hassler WE. Primary optic nerve sheath meningiomas: a follow-up study. Cent Eur Neurosurg 2010;71(3):126-33.

4. Miller NR. Primary tumours of the optic nerve and its sheath. Eye (Lond) 2004;18(11):1026-37.

5. Parsa CF, Hoyt CS, Lesser RL, Weinstein JM, Strother CM, Muci-Mendoza R, et al. Spontaneous regression of optic gliomas: thirteen cases documented by serial neuroimaging. Arch Ophthalmol 2001;119(4):516-29.

6. Chutorian AM, Schwartz JF, Evans RA, Carter S. Optic gliomas in children. Neurology 1964;14:83-95.

7. Listernick R, Ferner RE, Liu GT, Gutmann DH. Optic pathway gliomas in neurofibromatosis-1: controversies and recommendations. Ann Neurol 2007;61(3):189-98.

8. Bilgin G, Al-Obailan M, Bonelli L, Glasgow BJ, Vinters HV, Arnold AC. Aggressive low-grade optic nerve glioma in adults. Neuroophthalmology 2014;38(6):297-309.

9. Saeed P, Rootman J, Nugent RA, White VA, Mackenzie IR, Koornneef L. Optic nerve sheath meningiomas. Ophthalmology 2003;110(10):2019-30.

10. Harold Lee HB, Garrity JA, Cameron JD, Strianese D, Bonavolontà G, Patrinely JR. Primary optic nerve sheath meningioma in children. Surv Ophthalmol 2008;53(6):543-58.

11. Vanikieti K, Preechawat P, Poonyathalang A. Pediatric primary optic nerve sheath meningioma. Int Med Case Rep J 2015;8:159-63.

12. Tow SL, Chandela S, Miller NR, Avellino AM. Long-term outcome in children with gliomas of the anterior visual pathway. Pediatr Neurol 2003;28(4):262-70.

13. Brodovsky S, ten Hove MW, Pinkerton RM, Ludwin SK, Smith RM. An enhancing optic nerve lesion: malignant glioma of adulthood. Can J Ophthalmol 1997;32(6):409-13.

14. Dutton JJ. Optic nerve gliomas and meningiomas. Neurol Clin 1991;9(1):163-77.

15. Cummings TJ, Provenzale JM, Hunter SB, Friedman AH, Klintworth GK, Bigner SH, et al. Gliomas of the optic nerve: histological, immunohistochemical (MIB-1 and p53), and MRI analysis. Acta Neuropathol 2000;99(5):563-70.

16. Lee AG. Neuroophthalmological management of optic pathway gliomas. Neurosurg Focus 2007;23(5):E1.

17. Shofty B, Ben-Sira L, Kesler A, Jallo G, Groves ML, Iyer RR, et al. Isolated optic nerve gliomas: a multicenter historical cohort study. J Neurosurg Pediatr 2017;20(6):549-55

18. Wulc AE, Bergin DJ, Barnes D, Scaravilli F, Wright JE, McDonald WI. Orbital optic nerve glioma in adult life. Arch Ophthalmol 1989;107(7):1013-6.

19. Shapey J, Danesh-Meyer HV, Kaye AH. Diagnosis and management of optic nerve glioma. J Clin Neurosci 2011;18(12):1585-91.

20. Pasol J, Sternau L, Luetmer P, Giannini C. Rapid progressive unilateral visual loss in an elderly man. J Neuroophthalmol 2010;30(2):188-92.

21. Egan RA, Lessell S. A contribution to the natural history of optic nerve sheath meningiomas. Arch Ophthalmol 2002;120(11):1505-8.

22. Jin J, Joo JD, Han JH, Yang HK, Hwang JM, Kim YJ, et al. Optic nerve sheath meningioma: preliminary analysis of the role of radiation therapy. Brain Tumor Res Treat 2018;6(1):8-12. 